\title{
Poučevanje slovenskega jezika za Poljake v kognitivnem pristopu (izbrani vidiki) $^{1}$
}

\author{
Agnieszka BęDKowska-Kopczyk \\ Akademia Techniczno-Humanistyczna, Wydziat Humanistyczno-Społeczny, \\ Ul.Willowa 2,PL-43-309 Bielsko-Biała,kopczyk@poczta.onet.pl
}

\section{SCN II/2 [2009], 75-88}

Kognitivno jezikoslovje temelji na spoznanju, da jezik neposredno odraža človekove spoznavne procese. Pomen kot predmet nenehnega pogajanja ni vsota stalne vsebine besed, temveč načina, na katerem je ta vsebina konstruirana $\mathrm{v}$ določenem kontekstu; to je pogojeno $\mathrm{s}$ strukturo določenega jezika in pogledom na svet njegovih nosilcev. Tako dojemanje pomena vpliva na kognitivni pristop $\mathrm{k}$ prisvajanju tujega jezika. V prispevku je predstavljeno kognitivno razumevanje jezika in jezikovne didaktike, nato pa sledijo primeri iz slovenskega jezika, ki so konceptualno zahtevni za poljske študente slovenščine.

Cognitive linguistics is based on the assumption that language reflects human psychological processes. Meaning, as a subject of constant negotiation among people, is not just the conceptual content of the expression, it is the way in which the content is construed in a certain speaking context. It is influenced by both the structure of a given language and the vision of the world of its users. This view influences the cognitive linguistic approach to foreign language acquisition. This paper presents a cognitive approach to language and foreign language teaching; the theoretical section is followed by examples of Slovene expressions which are a conceptual challenge for Polish students of that language.

Ključne besede: kognitivno jezikoslovje, poučevanje tujih jezikov, slovenščina kot tuji jezik

Key words: cognitive linguistics, foreign languages teaching, Slovene as a foreign language

${ }^{1}$ Za posvetovanje glede jezikovnih razlik med poljščino in slovenščino se avtorica zahvaljuje Tatjani Jamnik. 
1 Slovenski in poljski jezik, ki spadata v slovansko jezikovno skupino, sta si podobna, vendar je pri poučevanju slovenščine za poljske študente moč opaziti ponavljajoče se slovnične napake, ki so zelo zanimive tako z vidika primerjalnega jezikoslovja kot jezikovne didaktike. Tem napakam se študentje lahko izognejo, če se zavedajo, da razhajanja med obema jezikoma zrcalijo različne poglede na določene elemente sveta oz. njihovo različno konceptualizacijo. Razlago teh razhajanj lahko opremo na kognitivno jezikoslovje, ki se sklicuje na dosežke spoznavne psihologije. Prvi del prispevka je namenjen približanju kognitivnega pristopa k jeziku in jezikovni didaktiki, ${ }^{2}$ drugi pa prinaša analizo izbranih jezikovnih primerov, ki predstavljajo težave za poljske študente.

1.1 Pridevnik kognitiven (oz. spoznavni) je moč v okviru jezikovne didaktike razumeti v povezavi vsaj s tremi teoretskimi pristopi:

- spoznavno psihologijo,

- tvorbno-pretvorbno slovnico N. Chomskega,

- t. i. kognitivnim jezikoslovjem.

Prvi temelji na spoznanjih kognitivne psihologije in je povezan s strukturo spomina (prim. Čok et al 1999: 21-26), ki je pomembna za učenje in poučevanje ne zgolj tujih jezikov, ampak vseh vrst učnih snovi. Spomin je psihična funkcija, ki omogoča pomnjenje in zapomnitev, ugotavljamo ga s priklicem fizičnih podatkov, predstav, občutkov, slikovnih in motoričnih podatkov (Razdevšek - Pučko v Čok et al 1999: 21). Če govorimo o kognitivnem pojmovanju spomina, človeka primerjamo s procesorjem informacij, pri tem je za vsakega posameznika značilen svojstven način in pristop pri procesiranju informacij ali svojstven spoznavni stil, tj. individualne posebnosti v spoznavni organizaciji in funkcioniranju glede na to, kako sprejema, organizira, ohranja in uporablja informacije (Razdevšek - Pučko v Čok et al 1999: 23-24).

Za naslednji dve teoriji, ki jih prikliče pridevnik kognitiven, je skupno to, da sta zrasli na področju jezikoslovja in se sklicujeta na dosežke spoznavne psihologije in psiholingvistike ter da učence usmerjata v zavestno prisvajanje sistema tujega jezika, zlasti slovničnih struktur. To, po čemer se obe metodi bistveno razlikujeta, je drugačen pristop k razmerju med mislijo in jezikom in $\mathrm{k}$ jezikovnemu sistemu nasploh.

\footnotetext{
${ }^{2} \mathrm{~V}$ zadnjem desetletju nastaja zmeraj več razprav v zvezi z uporabnimi vidiki kognitivizma, med katere poleg prevajanja in jezikovnega prisvajanja jezika s strani otrok spada tudi poučevanje tujih jezikov (prim. Tabakowska 2001, 2001a, Stanulewicz 2004). Za področje poučevanja slovenskega jezika za tujce je treba omeniti prispevek T. Jamnik (2004), v katerem avtorica v luči spoznanj kognitivnega jezikoslovja obravnava osnove češko-slovenskih medjezikovnih interferenc in njihov pomen med učenjem in poučevanjem slovenskega jezika s strani češkojezičnih študentov.
} 
Kognitivna metoda oziroma posodobljena slovnično-prevajalska metoda poučevanja tujih jezikov (modified, up-dated grammar-translation theory) ${ }^{3}$ je nastala v 60. letih dvajsetega stoletja v okviru tvorbno-pretvorbne slovnice N. Chomskyja (prim. Caroll 1966, Marton 1978). Za predstavnike tvorbno-pretvorbne slovnice je glavna funkcija jezika sporočanje misli, zato se ukvarjajo predvsem z opisovanjem jezikovne kompetence idealnega uporabnika jezika, torej njegove mentalne slovnice (Kurcz 2000: 88-90). Formalistične teorije, med katere lahko prištejemo tvorbno-pretvorbno teorijo, izhajajo iz prepričanja, da je jezik zgrajen iz ločenih in med sabo neodvisnih ravnin, kot so skladnja, fonologija in semantika. Tvorbeno funkcijo jezika $\mathrm{v}$ procesu oblikovanja in razumevanja stavkov generativisti povezujejo s skladnjo, se pravi s slovnico v ožjem smislu (Kurcz 2000: 89).

Znotraj kognitivnega jezikoslovja, ki se razvija od 70. let dvajsetega stoletja, se pristop $\mathrm{k}$ poučevanju tujih jezikov šele razvija. E. Tabakowska ta pristop imenuje sodobna slovnično-prevajalska metoda (Tabakowska 2001: 26, prim. dalje). Kognitivno jezikoslovje temelji na spoznanju, da jezik odraža človekove spoznavne procese (prim. mdr. Langacker 1987, 1991). Jezik - kot eno izmed orodij človeškega spoznanja - torej ni avtonomen, temveč je tesno povezan s človekovimi kognitivnimi zmožnostmi, kot so npr. percepcija sveta skozi čutno zaznavanje, nadgrajevanje informacij, ki so zbrane v možganih, s podatki, ki jih dobivamo prek čutil, mišljenje s pomočjo analogije, sinteze, abstrakcije, simbolov. Zaradi tega lahko to vrsto jezikoslovja uvrstimo med t. i. spoznavne vede. Po mnenju kognitivnih jezikoslovcev slovar, morfologija in skladnja tvorijo kontinuum simbolnih enot, ki z namenom, da izrazijo misel, strukturirajo konceptualne vsebine (Langacker 1987: 35). Kognitivisti predlagajo razlikovanje treh tipov struktur, in sicer fonološke, semantične in simbolne enote. Simbolna enota povezuje semantično in fonološko enoto (natančneje: semantični in fonološki pol te enote); to relacijo R. Langacker imenuje simbolizacija (1987: 76-77). Simbolnega pomena pa nimajo le leksemi, temveč tudi morfološke in sintaktične strukture; to pomeni, da je pravzaprav vsa slovnica »upomenjena«, kajti tudi slovnica našemu mišljenju daje določeno strukturo in simbolizira semantično vsebino. Najpomembnejši vidik tega pristopa je pomen, ki bi moral biti v središču pozornosti vsake jezikoslovne raziskave. Cilj kognitivistov je oblikovati tak model jezika, ki bi med drugim uspešno opisoval tako literarne kot metaforične primere, ki ne bi določal meja med normativnim in figurativnim načinom rabe jezika in opisoval t. i. jezik v rabi (language in use), med diahroničnim in sinhroničnim obravnavanjem jezikovnih problemov, predvsem pa takega, ki bi upošteval značaj govorca (torej njegov način mišljenja, individualnost, originalnost njegovega pogleda na svet, njegove čustvene reakcije itn.), ker prav ta značaj - skupaj s kulturnimi in družbenimi dejavniki - določa način rabe jezika. Značilnost kognitivizma je njegov interdisciplinarni pristop,

${ }^{3}$ Slovnično-prevajalska metoda se je že v 18. stoletju uporabljala za poučevanje predvsem klasičnih jezikov: učenci so posamezne odlomke besedila prevajali v tuji ali materni jezik in ob tem usvajali slovnično strukturo tujega jezika. 
saj kognitivisti v svojih razpravah radi segajo ne samo po dosežkih spoznavne psihologije, temveč tudi drugih disciplin, ki preučujejo značaj človeka, kot so antropologija, etnologija, sociologija idr. V razpravi se bom osredotočila na vidike kognitivizma, ki so povezani tudi s poučevanjem tujih jezikov.

$2 \mathrm{~S}$ tezo, da je jezik naše sredstvo za sporazumevanje, se verjetno strinjajo vsi jezikoslovni pristopi. SSKJ glagol sporazumevati se definira kot: 1 . 'z dogovarjanjem prihajati do medsebojnega razumevanja, sodelovanja' (npr. sporazumevati se za cene, državi sta se sporazumevali o novi pogodbi) in 2. 'izmenjavati, posredovati misli, informacije' (npr. sporazumevati se v tujem jeziku, mravlje se sporazumevajo s tipalnicami). E. Tabakowska (2001: 24) v svojem članku na temo triade sporazumevanje - prevajanje - didaktika drugi pomen tega glagola razlaga s pomočjo Reddyjeve metafore posode: ideje, misli, koncepte, informacije spravljamo govorci v posode (besede) in jih posredujemo našemu sogovorcu, ki jih potem iz teh posod »spravi ven« (Reddy 1979). Kot pravi avtorica je ta razlaga je verjetno primerna za dojemanje postopka sporazumevanja, vendar temelji na objektivistični predpostavki, da je vsebina teh posod (torej pomen besed ali izrazov) za zmeraj ustaljena in tako za pošiljatelja kot sprejemnika enaka. Ne upošteva torej dejstva, da na pomen lahko vpliva tudi kontekst, ki ga tukaj razumemo ne samo kot situacijo, ampak tudi npr. razpoloženje, kognitivne zmožnosti sogovorca. Te dejavnike lahko vključimo v prvi pomen glagola sporazumevati se, ki ga ponuja SSKJ, torej ' $\mathrm{z}$ dogovarjanjem prihajati do medsebojnega razumevanja, sodelovanja'. Tako razumevanje komunikacije je mogoče v okviru t. i. konstruktivističnega realizma (John Stuart Mill), ki ga upošteva kognitivna lingvistika (Tabakowska 2001).

Konstruktivistični realizem temelji na tem, da vsako spoznanje, ki izhaja iz izkušnje, predpostavlja aktivno sodelovanje osebe, ki do tega spoznanja prihaja, je torej ex definitione subjektivno. Spoznavni modeli ne odsevajo sveta, kakršen je, ampak takšen svet, kakršnega vidimo oz. si predstavljamo. Naši možgani ta svet oblikujejo in (so)tvorijo (Tabakowska 2001: 24). Semantične strukture (npr. besede, besedne zveze, slovnične kategorije), ki so proizvod našega opazovanja sveta in spoznavnih procesov, se razlikujejo od naroda do naroda, od posameznika do posameznika, ker jih določajo (kot smo že omenili) ne samo psihološki procesi, temveč tudi kulturni in družbeni dejavniki (npr. tradicija, kulturne sheme ali scenariji). K. Rajagopalan (2002) pravi, da je vsako sporazumevanje, celo med ljudmi, ki govorijo isti jezik, v bistvu že prevajanje, v katerem se lahko pomen izgubi. Pomembno je torej, da sogovorca zmeraj usklajujeta med sabo t. i. diskurzni univerzum, značilen za določen akt sporazumevanja, in ga nenehno modificirata ter rekonstruirata. Pomen torej razumemo po kognitivistih kot predmet nenehnega pogajanja, in to ne kot vsoto stalne vsebine besed, temveč kot rezultat govornega dejanja v določenem kontekstu. Tovrstnega pogajanja, katerega cilj je doseči čim boljši sporazum s svetom, se učimo hkrati s prisvajanjem maternega jezika. Pri pouku in poučevanju tujega jezika, kot trdi Tabakowska (2001), prideta na 
dan oba navedena pomena sporazumevanja. Najprej se učimo, kako najti in uporabljati posode in način, kako lahko pošiljamo svoje misli tujim sogovorcem (če posode metaforično razumemo kot besede, so torej način njihove rabe slovnična pravila). To fazo lahko poimenujemo prekladanje, ki ga razumemo kot prekladanje informacij iz ene posode $\mathrm{v}$ drugo. Nato se pojavi vprašanje, ali naš sogovornik v posodi res najde sporočilo, ki smo mu ga mislili posredovati. Če se izkaže, da nas oziroma našega sporočila ne razume tako, kot smo mislili, da bi ga lahko razumel, mu ga pojasnjujemo in razlagamo, dokler mu stvari ne postanejo konceptualno »jasne«.

3 E. Ohnuki-Tierney je opredelila faze človeškega spoznanja in sporočanja o svetu. Izločila je tri glavne faze, in sicer: precepcijo - konceptualizacijo simbolizacijo (Ohnuki-Tierney po Nowakowska-Kempna 1995: 109). V prvi fazi s čuti zaznavamo svet, v drugi podatke predelamo s pomočjo spoznavnih procesov in oblikujemo koncepte, $v$ tretji sporočamo o naših izkušnjah že s pomočjo leksikalnih struktur oz. simbolnih enot. Kognitivna lingvistika je sprejela tezo, da je način simbolizacije misli $\mathrm{v}$ jeziku popolnoma odvisen od načina njene konceptualizacije. Konceptualizacija je torej pomensko blizu pomenu, v katerem se objektivni elementi združujejo s subjektivnimi in tvorijo podobo sveta, ki je enaka za govorce istega jezika (dodajmo, da se v kognitivnih spisih pomen po navadi definira kot konceptualizacija, ne nasprotno). Ta podoba je na eni strani odvisna od percepcije tega sveta, na drugi strani pa je kulturno pogojena. Kot rečeno, med konceptualizacijo izkoriščamo vse spoznavne (kognitivne) zmožnosti, ki nam omogočajo predelavo informacij oz. njihovo procesiranje. V tej fazi se ločita tudi dva procesa, ki sta za kognitivino teorijo jezika izrednega pomena: metaforična preslikava (metaphorical mapping) in konvencionalno upodabljanje (conventional imagery) ali konstruiranje prizora (scene construal) (Langacker 1987: 99-145).

3.1 Teorijo metafore sta razvila G. Lakoff in M. Johnson (1980), ki sta ugotovila, da mesto metafore sploh ni zgolj v jeziku, temveč v mišljenju, in sicer v načinih, kako ljudje dojemamo en pojav v okviru drugega, npr. čas kot prostor (npr. sredi novembra) in predmet (npr. imeti čas), letne čase kot ljudi, ki se premikajo v prostoru (npr. bliža se pomlad), gospodarsko dejavnost oz. trgovino kot borbo (npr. osvojiti nove trge), podjetja kot vojsko ali športnike (npr. zmagovalec na trgu pralnih praškov) itn. Vse metafore, ne glede na to, ali so konvencionalne (najdemo jih v frazeoloških enotah) ali kreativne (npr. pesniške metafore), so koherentne in imajo konceptualne osnove, ki izhajajo iz človekove izkušnje: bodisi fizične (npr. doživljanje tridimenzionalnega prostora, opazovanje lastnega telesa in narave) bodisi kulturne (npr. ljudska, antična kultura, tradicija, civilizacijski oz. družbeni dosežki). Z drugimi besedami, izkušnja oblikuje naše predstave o svetu (predmetih, pojavih, ljudeh, odnosih), te pa se v možganih strukturirajo v obliki kognitivnih modelov. Konceptualna metafora je torej preslikava strukture kognitivnega modela z izhodiščnega področja (npr. v 
primeru metafore boriti se za zahodne trge našega vé denja o borbi) v ustrezno strukturo na ciljnem področju (npr. našega védenja o trgovini). ${ }^{4}$

3.2 Konvencionalno upodabljanje oz. konstruiranje prizora sta ključni besedi za kognitivno slovnico, ki jo je razvil R. W. Langacker (1987, 1991 in dr.), in (spet) pomen. Lahko ju razložimo kot določen način govorčevega oblikovanja sporočila oz. upodabljanja določene situacije. Lahko torej opišemo prostorsko razmerje nad/pod med dvema predmetoma na isti sliki: luč je nad mizo ali miza je pod lučjo. In prav imamo $\mathrm{v}$ obeh primerih, le da v prvem usmerimo pozornost sogovorca na luč, v drugem pa na mizo, vse pa je odvisno od konteksta sporočila in tega, kaj res želimo poudariti. Upodabljanje je torej naravna človekova sposobnost, ki se kaže, kadar isti pojav (prizor, situacijo, predmet) predstavljamo s pomočjo različnih razpoložljivih, alternativnih sredstev. Ta alternativna sredstva so v langackerjevi slovnici opredeljena kot razsežnosti upodabljanja in sodijo med zgoraj omenjene človekove kognitivne zmožnosti. Povezana so namreč z naslednjimi (mentalnimi in jezikovnimi) procesi: profiliranjem in stopnjo konkretnosti oz. shematskosti, določanjem perspektive in gledišča, orientacijo figura - ozadje, abstraktnim mišljenjem itn. Kot proces, ki se dogaja na konceptualni ravnini, spada sem tudi metaforična preslikava.

Znotraj določenega jezika je upodabljanje konvencionalno zato, ker mora govorec, da bi ustrezno upodobil svojo misel in posredoval sporočilo v skladu s svojimi potrebami in namerami, izbrati poljubno konstrukcijo iz repertoarja možnosti, ki mu jih ta jezik ponuja. Čeprav se vsi govorčevi izbori nahajajo v mejah konvencionalne rabe, kar pomeni, da so mu za izrazitev določene misli na voljo vse možne oblike, so lahko posamezni izbori bolj ali manj konvencionalni, odvisno od strategije oziroma sloga izrekanja (prim. Tabakowska 2001a: 48). Govorec slovenskega jezika lahko na primer reče: Janez ne prenaša Petra. Lahko pa uporabi frazem iti na živce (Peter gre Janezu na živce) ali to situacijo opiše na drug način. Jezikovni izrazi so pogosto funkcionalni ekvivalenti, saj se nanašajo na objektivno isti element zunajjezikovne stvarnosti. Različni pa ostajajo na semantični ravnini, kajti implicirajo različne, kontrastivne načine upodabljanja (ki se realizirajo z različno slovnično organizacijo, Langacker 1987: 39). To je posledica dejstva, da se lahko dva načina upodabljanja iste situacije med seboj razlikujeta po izboru značilnosti te situacije, ki so profilirane kot posebej pomembne, glede na stopnjo abstraktnosti in konkretnosti, s katero interpretiramo situacijo, glede na perspektivo, s katere jo opazujemo, in tako naprej (Langacker 1987: 111).

\footnotetext{
${ }^{4} \mathrm{~V}$ devetdesetih letih prejšnjega stoletja se je kognitivna teorija metafore na osnovi teorije mentalnih prostorov (mental spaces) razvila $\mathrm{v}$ teorijo spojin (bledning theory), $\mathrm{v}$ skladu s katero metafora nastaja kot povezava izhodiščnega področja (source space), ciljnega (target space) in področja spojine (blended space). Spojina je posledica projekcije izhodiščnega področja na ciljnega in vsebuje značilnosti obeh področij (Fauconnier, Turner 2002).
} 
3.3 Opisani procesi so univerzalni v tem smislu, da nastopajo v vseh jezikih, vendar so njihove konceptualne podlage izkušenjsko-kulturne narave, zato se posamezni jeziki med sabo razlikujejo. Te razlike so stvar stopnjevitosti - npr. v slovenščini in poljščini, kot v slovanskih jezikih, ki ju govorijo slovanski pripadniki evropske kulturne dediščine, obstaja veliko več konceptualnih podobnosti kot npr. v slovenščini in svahiliju.

4 Novejša psihološka literatura spomin obravnava po analogiji računalniških sistemov in ga primerja s sistemom procesiranja (zato človeka, kot smo prej omenili, pogosto primerjamo s procesorjem informacij). Priklic informacij je odvisen od načina vnosa in predelave le-teh. Procesiranje informacij bi moralo biti prilagojeno spominskim sposobnostim posameznega učenca. Pri tem je pomembno spoznanje, da obstajajo tri vrste spomina: senzorni register (trenutni, začasni spomin), kjer poteka prva selekcija informacij, ki pridejo v kratkotrajni (delovni) register, kjer še vedno poteka selekcija podatkov, ki na tej stopnji pomeni pretvorbo podatkov $\mathrm{v}$ simbolno obliko in s tem vstop $\mathrm{v}$ dolgotrajni spomin, ki ima neomejene zmogljivosti (Razdevšek-Pučko v Čok et al 1999: 22). Učitelj torej mora tako oblikovati postopek poučevanja, da učencem najprej omogoči čim boljši vnos podatkov v trenutni spomin, potem njihov prehod v kratkotrajnega in njihovo kodiranje $\mathrm{v}$ dolgotrajnem spominu. Prva učiteljeva naloga je torej pritegniti in ustrezno usmeriti pozornost učencev; to lahko dosežemo s tem, da oblikujemo pozitivna pričakovanja v zvezi z učno snovjo in na zanimiv način predstavimo informacije, ki jih za ta namen izberemo in oblikujemo tako, da jih učenec - na osnovi dosedanjega znanja lahko dojema. S tem lahko dosežemo, da nove informacije uspešno preidejo iz učenčevega začasnega spomina v kratkotrajnega. Druga naloga je povzročiti, da se v njegovem spominu ohrani čim več novih informaciji, in zagotoviti njihov večji pretok v dolgotrajni spomin. To lahko dosežemo s tem, da učencu zagotovimo čim bolj aktivno predelavo podatkov, in sicer s tem, da v tej fazi učinkovito aktivirajo svoje spoznavne procese, npr. skeniranje spomina in iskanje asociacij, primerjanje podatkov, abstrahiranje, kodiranje podatkov in pretok v dolgotrajni spomin. Učinkovito sprejemanje in procesiranje podatkov pri učencih ponovno vzbudi pozitiven odnos do učnega gradiva in pozitivna pričakovanja v zvezi z nadaljnjimi didaktičnimi postopki. In obratno - neuspeh pri usvajanju nove snovi lahko povzroči, da se učenec mentalno blokira in na ta način zapira svojo pot k nadaljnjemu razvoju na določenem področju. Zaradi tega se mi zdi pomembno pogovarjati se z učenci o njihovem učnem procesu in jih seznanjati z metakognitivnimi procesi, kot so zavedanje, nadzorovanje, usmerjanje in po potrebi spreminjanje lastnih spoznavnih procesov.

Kognitivisti predlagajo, da je za boljši vnos podatkov v trenutni spomin koristno poučevanje tujega jezika preusmeriti iz faze simbolizacije (torej leksikalizacije in strukture jezikovnega sporočila) v fazo konceptualizacije (torej spoznavnih procesov, ki se zrcalijo v jeziku). Po mnenju E. Tabakowske (2001: 26-27) bi morali učitelji tujih jezikov svoje študente učiti, kako se lahko zavedajo posameznih načinov konceptualizacije, na katerih temeljijo jezikovne 
strukture, in te načine potem med sabo primerjati. Tak didaktični postopek vključuje rabo metajezika, ker drugače nismo sposobni zavestno slediti poteku lastnih spoznavnih procesov. Za te namene nam bo v pomoč analiza diskurza - tako v tujem kot maternem jeziku. Kot pravi Tabakowska, moramo, da bi razumeli tuj način gledanja in dojemanja sveta, najprej spoznati svoj jezik in ga rekonceptualizirati. Šele kontrast nam bo pomagal najti razlike in podobnosti med jezikoma. To metodo avtorica imenuje »moderna slovnično-prevajalska metoda« in predlaga, naj jo - to je njeno že drugič posodobljeno različico uveljavljamo prav na osnovi spoznanj kognitivnega jezikoslovja. V nadaljevanju razprave predstavljam praktične vidike tega pristopa na primeru poučevanja slovenskega jezika za poljske študente.

5 Med slovanskimi jeziki obstajajo številne podobnosti v konceptualizaciji (tj. načinu dojemanja sveta); to je opazno tako na leksikalni kot skladenjski ravnini. Zaradi tega prihaja med slovanskojezikovnimi študenti, ki se učijo drugega slovanskega jezika, zelo pogosto do pozitivnega jezikovnega prenosa oz. mentalne preslikave lastnosti maternega jezika na tujega (prim. Jamnik 2004). Na osnovi večletne prakse pri poučevanju slovenskega jezika opažam, da poljski študentje izjemno hitro napredujejo pri pouku slovenskega jezika na osnovni stopnji, to je v razumevanju slovenskih govorjenih in zapisanih besedil ter tvorjenju preprostih besedil v slovenščini. Kljub podobnostim med obema jezikoma pa obstajajo tudi številna razhajanja, ki zrcalijo drugačen pogled na določene elemente sveta oziroma drugačno konceptualizacijo, kategorizacijo in jezikovno simbolizacijo le-teh (o njihovi vlogi na področju prevajanja mdr. v Pikala - Tokarz, Będkowska - Kopczyk 2002; Pikala - Tokarz 2007). Te razlike bom poskušala prikazati s pomočjo izbranih primerov, ${ }^{5} \mathrm{ki}$ jih interpretiram glede na eno od razsežnosti upodabljanja (dimensions of imagery, Langacker 1987: 110-116), to je določanje stopnje shematskosti (schematicity) in z njo povezane stopnje konkretnosti opisovanih elementov sveta (level of specifity) (Langacker 1987: 132-146). Navedla bom tudi nekaj primerov, ki zrcalijo dejstvo, da Poljaki in Slovenci na različne načine dojemamo odnose med objekti $\mathrm{v}$ tridimenzionalnem prostoru.

5.1 R. Langacker shematskost razume kot razmerje med shemo ${ }^{6}$ in njeno konkretizacijo, npr. koncept NOGA je shema za KOLENO, ki je hkrati konkretizacija te sheme (prim. definicijo kolena po SSKJ: 'del noge ob sklepu med golenjo in stegnom'). Shematskost/konkretnost v upodabljanju prizora je povezana tudi s tem, da lahko v opisu predmetov, ljudi, dogodkov upoštevamo detajle, ki so

\footnotetext{
${ }^{5}$ Primeri ponazarjajo najpogostejše napake v rabi slovenščine, ki jih ugotavljam v spisih in govoru študentov slovenskega jezika na Tehnično-humanistični akademiji v BielskemBiali.

${ }^{6}$ Langacker (1987: 168) je shemo opredelil kot semantično, fonološko ali simbolno strukturo, za katero je značilno, da je bolj splošna kot semantične reprezentacije, ki jih določamo v njenem okviru.
} 
za le-te značilni, odvisno od tega, kako natančno želimo opisati določen prizor (npr. NEKDO je v tem primeru lahko shema za: MOJ SOSED; MOJ SOSED MARKO; MOJ SOSED MARKO, KI STANUJE NASPROTI MENE itn.). Obstajajo pa primeri, ko nam jezik oziroma njegova slovnica način gledanja na svet in opisovanja le-tega do neke mere narekuje (prim. konvencionalnost govorčevih izborov v 3.2); to se pokaže, ko dva jezika primerjamo med seboj.

5.1.1 Za poljskega študenta slovenščine je prvo kognitivno presenečenje, s katerim se sreča pri učenju tega jezika, dvojina. V slovenščini namreč lahko število predmetov, oseb, pojavov opišemo bolj podrobno (oz. na višji stopnji konkretnosti) kot v poljščini, kjer se razlikuje samo med kategorijo posamičnih entitet (ednina) in kategorijo več kot ene entitete (množina). Dvojine kot slovnične kategorije za označevanje števila se Poljaki dokaj hitro naučijo uporabljati, vendar le v preprostih skladenjskih strukturah (npr. To sta dve punci. Imam dva brata.). V bolj zapletenih konstrukcijah, npr. pri osebnih glagolskih oblikah (v pretekliku ali prihodnjiku zlasti pri pomožnem glagolu) in sklanjanju dvojinskih osebnih zaimkov prihaja do značilnih napak (npr. križanje dvojinskih in množinskih končnic; o podobnih težavah pri čeških študentih poroča T. Jamnik 2004). To pomeni, da je za Poljake dvojina konceptualno dojemljiva, ${ }^{7}$ vendar je niso vajeni, zato jim jo je v govoru težko avtomatizirati.

5.1.2 Naslednja težava, s katero se poljski študentje soočajo pri učenju slovenskega jezika, je konceptualizacija razlike med statičnim in dinamičnim vidikom pri opisovanju prostorskih relacij; to se v slovenščini razen v rabi glagolov premikanja in glagolov, ki izražajo statične odnose, zrcali tudi v rabi:

- parov prislovnih zaimkov tu - sem in tam - tja,

- vprašalnih zaimkov kje in kam,

- tožilnika v predložnih zvezah z glagoli premikanja.

5.1.2.1 V slovenskem jeziku se pomensko razlikujejo zaimki z vidika izražanja dinamike prostorskih odnosov (prim. para tukaj/tu in sem; tam in tja), v poljščini pa z istim zaimkom (torej bolj shematsko) izrazimo tako dinamično kot statično situacijo: tutaj oz. njegova različica tu se uporabljata za 'tukaj' in 'sem' ter tam se uporablja za 'tam' in 'tja' (npr. Jestem tam na wakacjach 'Tam sem na počitnicah' in Jade tam na wakacje. 'Tja grem na počitnice.'). Zato morajo študentje premikanje oseb in predmetov poskusiti dojeti na »slovenski« način, torej doumeti in upoštevati, da je slovensko izražanje v tem primeru bolj konkretno in ponuja namesto ene dve možnosti: sem (in ne *tu), ko prihaja nekdo $\mathrm{z}$ neke točke v smer govorca, ter tja (in ne *tam), ko gre nekdo od govorca k nekemu cilju.

${ }^{7}$ Zaznamovanje dveh stvari je izkušenjsko znano vsem ljudem, npr. zaradi parnih delov telesa oz. organov. V poljščini najdemo ostanke staroslovanske dvojine ravno v primerih delov telesa, ki jih imamo po navadi v paru: oko, uho, roka, npr. dwoje oczu (mn. oczy), dwoje uszu (mn. uszy), dwoje rąk (mn. ręce). 
5.1.2.2 V poljskem tako kot $\mathrm{v}$ slovenskem jeziku obstajata dva vprašalna zaimka za izražanje smeri in prostora: za smer - dokad ('kam') in prostor - gdzie ('kje'). To bi lahko pomenilo, da je v tem primeru dinamika prostorskih odnosov izpostavljena $\mathrm{v}$ obeh jezikih, vendar ni tako, kajti v pogovorni poljščini se raba kje širi tudi na kam (npr. Dokad/Gdzie idziesz? 'Kam greš?'). To dejstvo pri študentih, vajenih pogovorne poljščine, povzroči, da se koncept dinamičnega prekriva s konceptom statičnega oziroma da se razlike med tema dvema konceptoma sploh ne zavedajo. V slovenskem jeziku torej pogosto nepravilno tvorijo vprašanja za smer, zlasti kadar prevajajo neposredno iz poljščine (npr. *Kje se seliš? *Kje si to dal? *Kje grě̌ na počitnice?). V tem primeru je treba študente seznaniti z dejstvom, da višja stopnja shematskosti v upodabljanju statičnih in dinamičnih prizorov znotraj maternega jezika in pomensko prekrivanje le-teh povzročata nepravilno uporabo navedenih zaimkov. Nato to spoznanje razširimo na slovenski jezik, v katerem sta statičnost in dinamičnost prizora upodobljena na višji stopnji konkretizacije, in sicer z uporabo različnih oziroma neidentičnih zaimkov.

5.1.2.3 Podoben postopek lahko uporabimo za razlago rabe tožilnika v slovenskih predložnih zvezah z glagoli premikanja. V poljskem jeziku je namreč poleg tožilnika (značilnega za opis dinamičnih situacij) mogoče uporabiti tudi mestnik (ki je značilen za opis statičnih situacij); pri tem se obe možnosti pojavljata tako v knjižnem kot pogovornem jeziku (npr. Książkę kładę na półce (mestnik) ali na półkę (tožilnik) 'Knjigo položim na polico.'). Zdi se, da v poljskem jeziku obstaja tendenca konceptualnega prekrivanja dinamičnega in statičnega upodabljanja situacije (pri tem prevladuje statično) - za ponazoritev tega dejstva lahko prikličemo stavek, v katerem v poljščini ni mogoče uporabiti drugega sklona kot mestnik: Jan pisze na tablicy (mestnik) 'Jan piše na tablo'.

5.2 Poljaki in Slovenci na različne načine dojemamo odnose med objekti v tridimenzionalnem prostoru, kar je tudi vir številnih jezikovnih napak pri poljskih študentih slovenščine (uporaba različnih sklonov). Kognitivizem odnose med objekti v prostoru razlaga s pomočjo t. i. shem podob, ki so definirane kot ponavljajoči se abstraktni vzorci, ki se oblikujejo v spoznavnih strukturah od prvih dni življenja, ko se človek začne gibati, premikati stvari ali kako drugače prostorsko zaznavati svet (Johnson 1987). Za preproste prostorske odnose so najbolj pomembne naslednje sheme: POSODA, POT in z njo povezani IZHODIŠČE in CILJ. V slovanskih jezikih so isti prizori v zvezi s premikanjem ljudi in predmetov kodirani s pomočjo drugačnih predlogov in sklonov; to je posledica dejstva, da Slovani: (1) na različne načine vidimo in dojemamo obliko izhodišča ali cilja premikanja ter (2) prizore upodabljamo na različne načine 
glede shematskosti in konkretnosti. ${ }^{8}$ Izbor primernega predloga in sklona ima torej pomensko motivacijo (kar na primeru drugih slovanskih jezikov podrobneje raziskujeta Janda 1993 in drugi ter Šarić 2008).

5.2.1 Za poljske študente slovenskega jezika se težave pojavijo tudi pri izražanju prostorskih razmerij, povezanih s premikanjem figure glede na obliko izhodišča. Poljščina ne razlikuje med predlogi, ki pomensko ustrezajo slovenskima $i z$ in $z / s$ (+ rodilnik) - oba lahko prevedemo s poljskim bolj shematskim zaimkom $z / z e$ (+ rodilnik). Pri Poljakih prihaja do pomenskega prekrivanja navedenih slovenskih predlogov, zato ju pogosto napačno rabijo v slovenskem jeziku, npr. *Prihajam iz trga, *Prihajam s kina. Konceptualno razliko med navedenimi slovenskimi in poljskimi primeri lahko pojasnimo s tem, da STAVBE (tako Slovenci kot Poljaki) konceptualno dojemamo kot POSODE, $\underline{\mathrm{v}}$ katere vstopimo in $\underline{\mathrm{iz}}$ katerih izstopimo, medtem ko TRGE dojemamo kot POVRŠINE, na katere stopimo in $\underline{s}$ katerih se vračamo. To sta najbolj prototipska primera delovanja shem POSODE in POVRŠINE (Johnson 1987), ki imata metaforične širitve, npr. izriniti koga iz srca, odstaviti koga s položaja, in če študentje ne dojamejo konceptualne razlike med njima, lahko postanejo vir napak.

5.2.2. Številne napake se pojavljajo tudi pri izražanju čustvenih razmerij, ki so metaforične širitve prostorskih odnosov med ljudmi. Objekte čustev lahko v obeh jezikih izražamo s predlogom na s tožilnikom (npr. złościć się na kogośbiti jezen na koga), ki v prostorskih odnosih izraža 'premikanje k zgornji strani česa, tako da nastane neposreden dotik, ali doseg takega položaja'. Ta predlog je metaforično razširjen na izražanje 'usmerjenosti duševne dejavnosti' (SSKJ). Objekt čustva torej dojemamo kot površino metaforičnega cilja, čustveni odnos pa kot približevanje površini metaforičnega cilja. Tak način izražanja čustvenega odnosa je v slovenščini pogostejši kot v poljščini, v kateri ni mogoče uporabiti istega predloga, ko govorimo na primer o objektu ponosa. V poljščini je objekt ponosa zmeraj konceptualiziran kot njegov vzrok; to izraža predlog z/ze $\mathrm{z}$ rodilnikom, ki je povezan $\mathrm{z}$ delovanjem sheme POSODE: być dumnym $z$ kogoś (dobesedno: *biti ponosen iz koga).

6 Poudarek konceptualizacije pri poučevanju tujega jezika učitelju tujega jezika ne bi smel pomeniti zgolj analize jezikovnih primerov oziroma primerjanja in razlaganja posameznih načinov upodabljanja prizorov. Zelo pomembne so tudi vaje, ki študentom pomagajo izboljšati prenos podatkov iz trenutnega $\mathrm{v}$ kratkotrajni spomin, nato pa $\mathrm{v}$ dolgotrajnega, kot tudi vaje za utrjevanje pridobljenega znanja. Zelo koristno je, da študente prosimo, naj sami pojasnijo konceptualne razlike med obema jezikoma ali naj razložijo cele skupine razlik (saj je s področja Gestalt psihologije znano, da so pojavi, opisani holistično,

${ }^{8}$ To je dokazano na primeru poljščine, ruščine, bolgarščine in slovenščine (Kaleta, Żeberek, Nowakowska-Kempna, Będkowska-Kopczyk 2004). 
pomensko enostavnejši, laže dojemljivi kot njihovi posamezni deli). Koristno je tudi spodbujati študente, naj se ob analizi posameznih primerov pogovarjajo o načinu kategorizacije sveta v poljski in slovenski kulturi, ker slovnične sestavine jezika, kot dokazujejo raziskave na področju kognitivne slovnice (Janda 2008), zrcalijo kulturno interpretacijo fizičnih pojavov. Študentom so lahko v pomoč tudi slavistične raziskave, ki nastajajo na področju kognitivizma (npr. Janda 1993, Šarić 2008, Sicherl 2007 idr.).

Ni treba poudarjati, da se pri pouku tujega jezika (kot tudi drugih predmetov) ne smemo omejevati le na eno metodo, saj ljudje, ki so nam dane različne inteligence (Gardner 1995), na različne načine sprejemamo nove informacije. Zato je pomembno uveljavljati metodološki pluralizem in uporabljati različne metode. Še pomembneje je vzbuditi pri učencih oz. študentih motivacijo za učenje, pri tem meni osebno pomaga pravilo »videti, da je kozarec napol poln, ne pa napol prazen« - na ta način skupaj s študenti gledamo in vidimo njihovo znanje jezika.

\section{BIBLIOGRAFIJA}

Agnieszka BĘDKOWSKA - KOPCZYK, 2004: Jezikovna podoba negativnih čustev v slovenščini. Kognitivni pristop. Prev. Tatjana Jamnik. Ljubljana: Študentska založba.

John B. CARROLL, 1966: Language and Thought. Englewoods Cliffs, New Jersey, Prentice Hall.

Lucija ČOK [et al.], 1999: Učenje in poučevanje tujega jezika. Smernice za učitelje v drugem triletju osnovne šole. Ljubljana: Univerza v Ljubljani, Pedagoška fakulteta, Koper: ZRS RS.

Gilles FAUCONNIER, Mark TURNER, 1998: Conceptual Integration Networks. Cognitive Science 22. 133-197.

Howard GARDNER, 1995: Razsežnosti uma: teorija o več inteligencah. Prev. I. Kovačič. Ljubljana.

Tatjana JAMNIK, 2004: Ali ima kača kljun? Konceptualna podlaga češko-slovenskih medjezikovnih interferenc. Jezik in slovstvo, 49/3-4, 91-102.

Laura Alexis JANDA, 1993: A Geography of Case Semantics: The Czech Dative and the Russian Instrumental. Berlin: Mouton de Gruyter.

,-- 2008: From Cognitive Linguistics to Cultural Linguistics. Slovo a smysl/Word and Sense, 8 (2008), 48-68.

Zofia KALETA, Teresa ŻEBEREK, Iwona NOWAKOWSKA - KEMPNA, Agnieszka BĘDKOWSKA - KOPCZYK, 2004: Imagery of the path-goal schema in Polish, Russian, Bulgarian and Slovenian. Imagery in Language. Ur. Barbara Lewandowska- Tomaszczyk. Frankfurt am Main: Peter Lang. 361-372. 
Ida KURCZ, 2000: Psychologia języka i komunikacji. Warszawa: Wyd. Naukowe SCHOLAR.

George LAKOFF, 1987: Women, Fire, and Dangerous Things. What Categories Reveal about the Mind. Chicago: University of Chicago Press.

George LAKOFF, Mark JOHNOSN, 1980: Metaphors we live by. Chicago: University of Chicago Press.

Ronald W. LANGACKER, 1987: Foundations of Cognitive Grammar, vol. I. Theoretical Prerequisites. Stanford: Stanford University Press.

- -, 1991: Concept, Image, and Symbol: The Cognitive Basis of Grammar. Berlin, New York: Mouton de Gruyter.

Waldemar MARTON, 1978: Dydaktyka języka obcego w szkole średniej. Podejście kognitywne. Warszawa: PIW.

Iwona NOWAKOWSKA-KEMPNA, 1995: Konceptualizacja uczuć w języku polskim. Warszawa: WSiP.

Bożena PIKALA - TOKARZ, Agnieszka BĘDKOWSKA - KOPCZYK, 2002: Imagery in Translations of Polish Poetry into Slovenian. Translation and Meaning, Part 6. Ur. Barbara Lewandowska - Tomaszczyk, Marcel Thelen. Maastricht: Hogeschool Zuyd Maastricht School of Translation and Interpreting. 283-289.

Bożena PIKALA-TOKARZ 2007: Slovnične kategorije v prevodu na primeru slovenskih in poljskih prevodov. 31. zbornik Društva slovenskih književnih prevajalcev. Ur. Martina Ožbot. Ljubljana: DSKP. 157-167.

Kanavillil RAJAGOPALAN, 2002: Translation as a Process of Meaning Negotiation: Some Implications for the Semantics of Natural Languages. Translation and Meaning, Part 6. Barbara Lewandowska-Tomaszczyk, Marcel Thelen. Maastricht: Hogeschool Zuyd Maastricht School of Translation and Interpreting. 131-136.

Michael REDDY, 1979: The Conduit Metaphor. Metaphor and Thought. Ur. A. Ortony. Cambridge: University Press. 284-324.

Eva SICHERL, 2007: Radialni model angleškega predloga on v odnosu do slovenskega predloga na. Slavistična revija 55/2007, 559-579.

Danuta STANULEWICZ, 2004: Językoznawstwo kognitywne a nauczanie języków obcych. Języki obce w szkole, 1/2004. 5-11.

Slovar slovenskega knjižnega jezika, 1970-1991 (tudi elektronska izdaja). Ljubljana.

Ljiljana ŠARIĆ, 2008: Spatial Concepts in Slavic. A Cognitive Linguistic Study of Prepositions and Cases. Wiesbaden: Harrasowitz Verlag.

Elżbieta TABAKOWSKA, 2001: Komunikacja-przekład-dydaktyka. Materiały z XXI Sympozjum zorganizowanego przez Instytut Lingwistyki Stosowanej UW i Polskie Towarzystwo Lingwistyki Stosowanej, Warszawa, 29-30 maja 2000 r. Red. Andrzej Kopczyński, Urszula Zaliwska-Okrutna. Warszawa: Wydawnictwo Uniwersytetu Warszawskiego. 23-33.

- -, 2001a²: Językoznawstwo kognitywne a poetyka przekładu. Prev. Agnieszka Pokojska. Kraków: Universitas. 


\section{TEACHING POLES SLOVENE LANGUAGE USING A COGNITIVE APPROACH (SELECTED ASPECTS)}

Polish and Slovene belong to the same language group and thus they share many grammatical features. However, when Polish students learn Slovene, they make a number of recurrent mistakes that are interesting from the point of view of both comparative linguistics and language teaching. These mistakes are analyzed in this paper by means of the tools of cognitive grammar. I present a cognitive approach to language and foreign language teaching; the theoretical section is followed by examples of Slovene expressions which are a conceptual challenge for Polish students of that language. Cognitive linguistics is based on the assumption that language reflects human psychological processes, and that every single process of grammar construction is meaningful. Meaning, as a subject of constant negotiation among people, is not just the conceptual content of the expression, it is the way in which the content is conceptualized and construed in a certain speaking context. This content is influenced by the structure of a given foreign language, the vision of the world of its users, and their social interaction. This view has an influence upon the cognitive approach to foreign language teaching which should, among other things, make students aware of the ways of conceptualizations and the ways of the construal of the meaning which underlies both foreign and native language expressions. Such a procedure facilitates foreign language acquisition. The assumptions of the cognitive method (described by E. Tabakowska as a modern grammar-translation method) agree therefore with the assumptions of cognitive psychology, according to which the retrieval of information is dependent on the nature of its input to memory. 